Schlumpf, Sandra (2017): «Language contacts in modern Judeo-Spanish: Notes on the concessive and concessive conditional clauses», Lingua 194, pp. 1-14,

http://www.sciencedirect.com/science/article/pii/S0024384117300773. DOI: 10.1016/j.lingua.2017.05.008

\title{
Language contacts in modern Judeo-Spanish: notes on the concessive and concessive conditional clauses
}

Abstract: Since the beginning of the Sephardic diaspora in the Ottoman Empire, JudeoSpanish has been in contact with different languages, both romance and others. The lexical borrowings from these languages are a characteristic element of Judeo-Spanish, especially the Hebraisms of the classical period (until the beginning of the $19^{\text {th }}$ century) and the Gallicisms of the modern period (from the middle of the $19^{\text {th }}$ century onward). The results of these language contacts have seldom been analyzed from a syntactical point of view, a fact that reflects the general lack of detailed studies about Judeo-Spanish syntax. The aim of this paper is to summarize the results of language contacts that can be observed in the concessive and concessive conditional clauses in modern Judeo-Spanish texts, published between 1880 and 1930. First, we see an increase and a diversification of the concessive conjunctions due to the contacts with Western European languages, especially Italian. Second, a linguistic innovation in the concessive conditional clauses reflects the fundamental changes in the language contacts of Judeo-Spanish between the $18^{\text {th }}$ century and the modern period, as well as the modernization of Judeo-Spanish that characterizes its transformation during the last decades of the $19^{\text {th }}$ and the beginning of the $20^{\text {th }}$ centuries.

Keywords: Judeo-Spanish; language contacts; concessive clauses; concessive conditional clauses; conjunctions

\section{Introduction}

Its considerable number of loanwords is one of the best-known and regularly repeated characteristics of Judeo-Spanish, the language spoken by the descendants of the Jews who were expelled from the Iberian Peninsula at the end of the $15^{\text {th }}$ century and who settled in high number in the Ottoman Empire. However, at least until the $19^{\text {th }}$ century, it's not so much the quantity of loanwords that distinguish Judeo-Spanish from other Spanish varieties, but rather the origin of these lexemes (cf. Schmid 2008: 62-64). Hebraisms are mainly used to name concepts related to the Jewish religion, its institutions and its cultural elements (e.g., bet din 'rabbinical tribunal', quehilá 'synagogue', tefilá 'prayer'), and it's also possible to find syntactical influences of Hebrew, first in translations of Hebrew texts to Judeo-Spanish (Hassán 1995: 128). Turkisms generally are related to the civil and military administration 
(e.g., asquier 'soldier'), the urban and material life (e.g., meidán 'public square'), titles (e.g., chelebi 'sir') and more abstract concepts (e.g., tafrá 'arrogance'). Italianisms can be found in commercial vocabulary due to Italy's dominant role in the commercial activities of the Eastern Mediterranean (e.g., valuta 'value', avocato 'lawyer'). Finally, loanwords from Greek and Slavic languages also can be found, although in a much lower quantity.

In the $19^{\text {th }}$ century, in the course of the profound transformations that occurred in the Ottoman Empire and also affected the life and language of the Sephardic communities, the importance of the cited contact languages declined. Sociopolitical and cultural changes and innovations produced new linguistic and cultural contacts, which played an important role in the modernization of Judeo-Spanish from the middle of the $19^{\text {th }}$ century onward. Whereas in earlier centuries Hebrew was the most relevant contact language of Judeo-Spanish, in the modern period this influence comes from Western European languages, primarily French and Italian. Thanks to its symbolic function as a language that represents modern life, emancipation and progress, French soon assumed linguistic leadership in the transformation of Judeo-Spanish in the late $19^{\text {th }}$ and early $20^{\text {th }}$ centuries. Lexical elements that design inventions of the modern world are the most obvious impact of these recent language contacts, but they can also be found in more grammatical elements of the language, such as conjunctions or the use of verb tenses and moods in certain types of sentences. The syntactical results of these modern language contacts have not been thoroughly analyzed, a fact that reflects the general lack of detailed studies about the Judeo-Spanish syntax and the syntax of complex sentences in particular.

The aim of this study is to look for possible results of the mentioned modern language contacts in a concrete part of the Judeo-Spanish syntax; that is, the concessive and concessive conditional clauses. Therefore, in the following pages, we will first summarize some fundamental aspects about the sociopolitical and historical context of the Ottoman Empire in the late $19^{\text {th }}$ and early $20^{\text {th }}$ centuries. This will help to clarify the circumstances that led to the profound transformations in the life of the Sephardic communities in the Empire, including the linguistic modernization. Later, we will briefly present the corpus of Sephardic texts on which the following analysis is based: the corpus MemTet of the University of Basel, Switzerland, with Sephardic texts published between 1880 and 1930. In the second part of the article, we will turn to the concessive and concessive conditional clauses: after some theoretical remarks about these types of sentences, we will show the results of language contacts in this particularly complex and scarcely investigated part of Judeo-Spanish grammar. The article finishes with some concluding remarks. ${ }^{1}$

\footnotetext{
1 We thank the anonymous reviewers for their careful reading of our manuscript and their helpful comments and suggestions.
} 


\section{The Ottoman Empire in the late $19^{\text {th }}$ and early $20^{\text {th }}$ centuries and the modern Judeo- Spanish}

This study talks about the written Judeo-Spanish of Sephardic texts published in the Eastern Mediterranean region between 1880 and 1930. These decades represent the Golden Age of the modern Judeo-Spanish text production, which reflects the transformation and modernization of the Sephardic language initiated around 1850. This modernization process is a consequence of broader transformations in the Ottoman Empire during the $19^{\text {th }}$ century: numerous problems of the Empire (weak government, huge and inefficient bureaucracy, corruption, economic difficulties, supply problems, lack of modernization, civil wars, etc.) and a broad discontent in major parts of the society, followed by anti-Semitic riots and social uprisings in several regions, forced the Empire to take measures (cf., e.g., Barnaï 1992: 142151; Faroqhi 2003: 251-255; Veinstein 1993: 364-366). First, the government increased taxes. This was especially problematic for the religious minorities, who were required to pay not only the general taxes but also the additional jizya tax in order to maintain some special rights, such as exemption from military service and a high degree of communal autonomy (for example, in religious, educational, administrative and judicial affairs). Second, in the course of the reformation period called tanzimat 'regularization, organization, new order' (1839-1876), the Empire pushed the modernization and secularization of state facilities such as the political apparatus, infrastructure, medical and educational system and armed forces. ${ }^{2}$ Third, it opened its doors for the first time to Occidental European countries, which took advantage of this new situation and started to influence the Ottoman trade. Despite all efforts, the Ottoman Empire did not succeed in re-establishing public order and a strong centralized government, nor was it capable of stopping the gradual disintegration of the Empire. New nation states emerged in the region (e.g., Greece, Serbia, Macedonia, Bulgaria, Romania), and finally the Ottoman Empire was dissolved with the proclamation of the Republic of Turkey in 1923.

The mentioned transformations also widely affected the Jewish communities of the Ottoman Empire. After many centuries of relative security thanks to the millet system that regulated the life of the religious and ethnic minorities in the Empire, the Reform edict Hatt-i Hümâyûn of 1856 abolished the special dhimmi status of the non-Muslims. ${ }^{3}$ Therefore, they could no longer benefit from special protection through the Ottoman government and were

\footnotetext{
2 Information about the Ottoman reforms in the $19^{\text {th }}$ century and, in general, about the period of modernization and secularization of the Empire can be found in Benbassa and Rodrigue (2004: 173-184), Faroqhi (2003: 275281), Levy (1992: 98-104), Shaw (1991: 147-187), Veinstein (1993: 366-367) and Weiker (1992: 115-148).

${ }^{3}$ Further information about the organization of the Sephardic communities in the Ottoman Empire and about the millet system can be found in Levy (1992: 42-70), Shaw (1991: 41-44) and Weiker (1992: 49-74).
} 
more often victims of religious riots. In the whole Eastern Mediterranean region, and especially on the Balkans, anti-Semitic riots increased (cf. Veinstein 1993: 368). In addition, the intensified contacts between the Empire and the Western European countries, whose presence led to an improved status for Christians in the Empire, were disadvantageous for the Jews, who lost many influential positions in the Ottoman administration. These circumstances forced the Jewish elites to seek support outside the Ottoman boundaries. They found it in the Jewish communities of Western Europe, whose influence on the Ottoman Jewry started to drastically intensify, especially through the European schools that were established in many Ottoman towns (cf. Romero 2008a: 178-180). Examples include the Italian schools of the Società Dante Alighieri,4 the Viennese schools of the Camondo family (cf. De Benmergui 2007) and, most important, the French schools of the Alliance Israélite Universelle (AIU). ${ }^{5}$

The AIU was founded in 1860 in Paris by a group of liberal Jewish bourgeois, who wanted to spread the ideas of the Enlightenment (i.e., liberalism, equality, emancipation, reason and secularization) throughout the Jewish world. The AIU opened its first school in the Ottoman Empire in 1862 in Tétouan, Morocco (Benbassa and Rodrigue 2004: 201), followed by many school foundations all around the Empire (kindergartens, primary and secondary schools, vocational schools, etc.). In 1912, all Sephardic communities in the Empire with a thousand or more inhabitants had an AIU school (Benbassa and Rodrigue 2004: 202), and up to 1940, according to Weiker (1992: 198-199), 205 AIU schools were founded in what are now fifteen different countries. For the first time, girls also gained access to the educational system in the Jewish communities of the Empire (Benbassa and Rodrigue 2004: 202). All these AIU schools represented the French school system in Ottoman territory: the educational guidelines and timetables were almost identical to the ones in France and the classes were taught in French, providing strong contrast to the traditional schools of the Ottoman Jewish communities in which Judeo-Spanish was the main language of education. Additionally, Hebrew and local languages like Turkish were taught. In only a few years, the schools of the AIU turned into well-recognized institutions of modern, laical education, and the French language and culture were seen as symbols of emancipation and modernity. The way of life in the Jewish communities was transformed, influenced by the modern lifestyle in Western Europe and especially in France. Although only a limited part of the Jewish society could attend the European schools - and most of them attended the AIU schools only for a

\footnotetext{
4 Cf. http://www.ladante.it (accessed 31 October 2016).

${ }^{5}$ About the Alliance Israélite Universelle and the transformation in the educational sector of the Sephardic communities in the $19^{\text {th }}$ century, see Benbassa and Rodrigue (2004: 200-211), JE (s. v. Alliance Israélite Universelle), Levy (1992: 112-115), Lévy (1990), Molho (1993), Rodrigue (1990: 71-99; 1993: 7-21), Shaw (1991: 159-166) and Weiker (1992: 193-214).
} 
few years (Benbassa and Rodrigue 2004: 206) -, they had a positive impact on Jewish life in the Ottoman Empire as a whole (e.g., foundation of libraries, social and literary clubs, charity organizations for the poor, orphans and old people). A new Sephardic elite came into being along with a secular, multilingual and multicultural education, very different from the traditional, religious leaders of the Sephardic communities; therefore, it's not surprising that conflicts arose between that traditional, religious elite and the new secular, Europeanoriented community leaders.

In regard to the language, the importation of modern text genres was of crucial importance. The so-called géneros adoptados 'adopted genres' - press, narrative, secular theatre and autographed poetry - quickly became an important medium through which the new ideas and linguistic features spread in the Sephardic communities. ${ }^{6}$ Journalists were especially aware of their influence in the diffusion of national and international news, modern progressive views and topics, as well as lexical and conceptual innovations in their newspapers and journals (cf. Schmid 2008: 69-71). Some of the most important Sephardic journals were founded in the last decades of the 19th century: La Buena Esperanza (Smyrna, 1871), El Tiempo (Istanbul, 1871), La Época (Salonika, 1875), El Telégrafo (Istanbul, 1879) and El Avenir (Salonika, 1898), among others. ${ }^{7}$ The most splendid years of the Sephardic press in the Ottoman Empire were the ones following the Young Turk Revolution (cf. Britannica, s. v. Young Turks) against the despotic regime of Sultan Abdul Hamid II in 1908, which led to the restoration of the Ottoman constitution of 1876 and the abolishment of press censorship. In the case of the literary genres, ${ }^{8}$ besides original Sephardic works, many translations to Judeo-Spanish from French authors like Molière (L'Avare, Le Malade imaginaire, ${ }^{9}$ Le Médecin malgré /ui, etc.), Victor Hugo (Les Misérables), Émile Zola and Alexandre Dumas were published, as well translations from German (e.g., Goethe's famous Werther), English (e.g., works from Shakespeare and George Bernard Shaw), Italian (e.g., Goldoni) and Russian (e.g., Tolstoy and Dostoevsky). Without any doubt, the most important cultural and literary, as well as linguistic, influence was the French one. The French language, literature and culture became the new emblems of modern and educated life in the Sephardic communities.

\footnotetext{
${ }^{6}$ About the importance of these adopted genres in the Sephardic communities of the Ottoman Empire since the middle of the $19^{\text {th }}$ century, see especially Romero (1992: 177-312; 2007: 191-201; 2008a: 178-186) and DíazMas (2006: 94-212).

7 About the Sephardic newspapers and the periodization of the Sephardic press, see Bürki (2012b: 41-47), Gaon (1965) and Hassán (1966).

8 Consult Romero (1979 and 2008b) for the Sephardic theatre, and Cimeli (2013: 14-30) as an introduction to the Sephardic narrative literature.

9 Schmid and Bürki (2000) offer an edition and linguistic study of the Sephardic version of Molière's Le Malade imaginaire.
} 
Before the outlined historical and sociopolitical background, and thanks to the cultural and linguistic innovations, the Judeo-Spanish language was transformed and modernized. Processes of language elaboration characterize the evolution of the Sephardic language during the last decades of the $19^{\text {th }}$ and the first decades of the $20^{\text {th }}$ centuries; its result is known as modern Judeo-Spanish or neo-Judeo-Spanish (cf. Schmid 2008). These transformations were necessary to react to new needs, both of the Sephardic authors, journalists and publishers and of the readers of the recently introduced text genres. Personal contacts between the Ottoman Jews and their coreligionists in Europe also improved the linguistic elaboration process. Many loanwords from Western European languages were adapted to Judeo-Spanish, sometimes because no equivalent term existed in JudeoSpanish, but other times in order to substitute another, more traditional expression; for instance, a Hebrew or Turkish word. Some examples of such Occidental loanwords, first of all Gallicisms, are: angajamiento < French engagement 'engagement', dota < French / Italian dote 'dowry', promenada < Fr. promenade 'promenade', randevú < Fr. rendez-vous 'appointment', vestón < Fr. veston 'jacket' (Sánchez 2010: 90); anvelopes < Fr. enveloppes 'envelope', asansor < Fr. ascenseur 'elevator', camino de fiero < Fr. chemin de fer 'railway', cartier < Fr. quartier 'district', garźón < Fr. garçon 'boy', ovrador < Fr. ouvrier 'worker' (Rieder-Zelenko 2014). Additionally, new stylistic, discursive and grammatical elements were adapted from French and Italian; for example, verbal periphrases such as venir de + infinitive $<$ Fr. venir de + infinitive 'to have just done something' and no mancar de + infinitive < Fr. ne pas manquer de + infinitive 'to be sure to do something' (Schmid and Bürki 2000: 158-159) or the relative pronoun donde < Fr. dont, which is used beside the patrimonial solutions de su and el cual: "La España traversa en esta hora una criś donde la fin puede ser muy deśastrośa" (Bürki 2012a: 132). Also in the concessive sentences in modern Sephardic texts we can find innovative linguistic elements, as we will comment later. Altogether, these linguistic innovations led not only to the modernization of the Judeo-Spanish language, but also to its occidentalization and re-romanization.

\section{The corpus of Sephardic texts MemTet (University of Basel, Switzerland)}

The following study about concessive clauses in modern Judeo-Spanish is based on the corpus MemTet from the University of Basel, Switzerland. This corpus of Sephardic texts was established from 2003 to 2004 within the project "Entre tradición y modernidad: El judeoespañol de Oriente entre 1880 y 1930 [Between tradition and modernity: The Oriental Judeo-Spanish between 1880 and 1930]" under the direction of Prof. Dr. Beatrice Schmid.10

\footnotetext{
10 Further information about the linguistic investigation on Judeo-Spanish at the University of Basel, Switzerland, can be found on: http://ladino.unibas.ch. A description of the cited project is available on: http://ladino.unibas.ch/proyectos/entre-tradicion-y-modernidad. For more information about the corpus MemTet,
} 
The total extension of the corpus is about 522,000 words. All the Sephardic texts included in MemTet were published, originally in Hebrew characters (aljamía), during the mentioned decades in the following cities in the Oriental Mediterranean region: Cairo, Smyrna, Istanbul, Jerusalem, Ruse (Bulgaria), Salonika, Sarajevo, Sofia and Xanti (Greece). MemTet includes both original Sephardic texts and translations from other languages. All the texts refer to nonreligious contents and comprise different text genres: literary texts (plays, short stories and novels), humoristic texts, press texts (newspapers and journals), administrative and legal texts, conference texts and lectures, and a series of texts without any clear assignment to any genre, therefore classified as varia. In the examples cited in this article, the genres will be apparent from the minuscule included in the references indicated: $a=$ administrative texts, $\mathrm{c}=$ conferences, $\mathrm{d}=$ lectures (discursos) $\mathrm{h}=$ humoristic texts, $\mathrm{n}=$ narrative texts, $\mathrm{p}=$ press texts, $\mathrm{t}=$ plays $($ teatro $), \mathrm{v}=$ varia.

The corpus MemTet represents the variety and abundance of the textual production in Judeo-Spanish between 1880 and 1930. These five decades are characterized by many important political, social and cultural transformations in the Ottoman Empire and, consequently, in the life of the Oriental Sephardic Jews (see Section 2). Regarding the language, this half-century reveals the numerous lexical and grammatical innovations that are the result of the elaboration and modernization process initiated in the middle of the $19^{\text {th }}$ century and which transformed the classical Judeo-Spanish into the modern Judeo-Spanish, influenced strongly by the contacts with European languages, above all the French language. Therefore, MemTet constitutes a representative corpus that serves to carry out linguistic studies about the Sephardic language in the modern period, the last Golden Age of the Judeo-Spanish language before the start of its decline. ${ }^{11}$

\section{Results of language contacts in the concessive and concessive conditional clauses in modern Judeo-Spanish}

\subsection{Some general remarks on the meaning of concessives}

Generally, concessive clauses are considered one of the most complex types of sentences, both on a formal and on a semantic level. Many different linguistic structures may serve as concessive markers, and most of them show a composed and semantically transparent form. Typical examples in English and Spanish are: although, albeit, even though, in spite of,

see: http://ladino.unibas.ch/proyectos/entre-tradicion-y-modernidad/el-corpus-memtet. The name of the corpus MemTet includes two letters of the Hebrew alefato, mem and tet, which represent two words of the project's title: modernidad 'modernity' and tradición 'tradition'.

${ }^{11}$ About the reasons for the decline of Judeo-Spanish, see the different publications of Tracy K. Harris (1982; 1985; 1994: 195-265), as well as Benbassa and Rodrigue (2004: 211-239), among others. 
despite, regardless; aunque, a pesar de, pese a, si bien (cf. König 1985: 266-269; König 1988: 151-156). In this context, it's worth mentioning that the Romance languages didn't take over the concessive expressions from Latin, but created their own set of concessive markers. From a semantic point of view, the concessive sentences express in their two clauses two facts that normally do not go together or whose causal relationship produces some kind of astonishment. Accordingly, the fact related by the principal clause normally is surprising and unexpected for the audience given the premise stated in the subordinate clause. At the same time, the concessive clauses serve to express the non-realization of a causal relationship between two facts that relate to one another; in other words, that stand in a logical, causal connection (cf. König 1991: 633). Therefore, the concessive meaning of a specific sentence only becomes clear if it activates some general knowledge in the audience, a so-called presupposition, which helps to correctly interpret the sentence. For example, the following concessive sentence: "Although John had no money, he went into this expensive restaurant" entails, firstly, the concrete presupposition "If John has no money, he normally does not go into an expensive restaurant" and, secondly, the general presupposition "If one has no money, one normally does not go into an expensive restaurant" (König 1988: 146147). The concessive sentence gains its specific meaning because it points to such general knowledge about causal relations between two facts: someone has no money; therefore, he/she does not go into an expensive restaurant. This knowledge or presupposition, implicitly present in a concessive sentence, allows the formulation of another, not expected result, which therefore seems surprising: someone has no money; nevertheless, he/she goes into an expensive restaurant (cf. Rivarola 1976: 4-5). According to Di Meola (1998), this is the main difference between causal and concessive relations: whereas the former express both a result and its direct cause, the latter mention a non-operating, thus inefficient fact and a result caused by another, unmentioned circumstance (for example, we may assume that John went into that expensive restaurant because someone had invited him).

As far as Judeo-Spanish is concerned, no studies about concessive clauses existed before the publication of Schlumpf (2015). This fact is only one example illustrating the general lack of broad studies about the morphosyntax of the Sephardic language, in contrast to a considerable series of phonetic and lexical studies. However, it's the morphosyntactical level where we can observe how far linguistic transformations resulting from new sociopolitical and cultural circumstances or from new language contacts can reach, not only in the lexicon, but also in the grammar of a language. Therefore, the analysis of the concessive clauses is an important contribution to the study of the far-reaching modernization processes that characterized the evolution of Judeo-Spanish in the late $19^{\text {th }}$ and early $20^{\text {th }}$ centuries. 
In the following analyses, we will first comment on the two concessive conjunctions most frequently used in the corpus MemTet (see Section 4.2). One is a patrimonial conjunction of Castilian origin; the other is an innovative form that was introduced to the Sephardic language in the second half of the $19^{\text {th }}$ century as a result of the intensive linguistic and cultural interaction with French and Italian.

Second, in Section 4.3, we will observe an ongoing process of linguistic substitution in the field of the so-called concessive conditional clauses (cf. Haspelmath and König 1998; Flamenco García 1999: 3842-3849). From a typological point of view, the concessive conditionals are situated between the conditional and the concessive sentences and have certain characteristics in common with both. Three types of concessive conditionals can be distinguished: scalar concessive conditionals, alternative concessive conditionals and universal concessive conditionals, and all of them share common semantic properties. On the one hand, concessive conditionals can be analyzed as a special type of conditionals (cf. Haspelmath and König 1998: 564-566; König 1985: 264; König 1991: 635; König and Eisenberg 1984: 315): they "exhibit the same combinations of tense and mood also found in ordinary conditionals" and they "express a conditional relationship between a protasis and an apodosis" (Haspelmath and König 1998: 564 and 565). But whereas the conditional subordinate clauses formulate only one condition, in the concessive conditionals the protases relate to a series of conditions. In addition, and again in opposition to the conditional sentences, the concessive conditionals usually entail the positive assertion of the apodosis (consequent), no matter what unfavorable conditions are mentioned in the protasis; therefore, authors like König (1985: 264-265) also call them irrelevance (concessive) conditionals. On the other hand, the concessive conditionals also show certain common characteristics with concessive sentences (cf. Haspelmath and König 1998: 566-568 and 576): as in the concessives, the set of conditions activated by the protases of concessive conditionals carries "an implication of incompatibility between two situations. Among the protases related by such conditionals to an apodosis, there is at least one case [...] that is in conflict with the apodosis" (König 1988: 147) or that produces some kind of surprise.

In the case of scalar concessive conditionals, which will be treated in the following analyses of the Sephardic examples, "a series of antecedents is specified by asserting a conditional relationship for an extreme (unlikely) value on a scale. By implication, this relationship can also be assumed to obtain for other values on the same scale. The consequent is asserted to hold under any of the conditions specified by the antecedent" (König 1985: 264). Two English examples are: "Even if we do not get any financial support, we will go ahead with our project" (Haspelmath and König 1998: 563); "Even if you drink just a little, your boss will fire you" (König 1985: 264). From a formal point of view, the scalar concessive conditionals are characterized by their transparent and semantically 
compositional structure. In languages with predominantly finite subordination, they are formed using subordinating, frequently conditional conjunctions, in combination with a focus particle which usually precedes, but in some languages can also follow, the conjunction: even if in English, incluso siand ni siquiera si in Spanish, même si / si même in French, se anche / anche se in Italian, mesmo que, ainda que y nem que in Portuguese, selbst wenn, auch wenn / wenn auch in German, etc. (cf. Haspelmath and König 1998: 585-586; König 1981; Rodríguez Rosique 2008: 269-341).

\subsection{The two main concessive conjunctions of modern Judeo-Spanish: Castilian heritage and modern Romance influence}

We will turn now to the analysis of the most common concessive conjunctions used in the Sephardic texts included in the corpus MemTet. The total number of concessive sentences found in the corpus is 309 , which is limited in comparison with other types of sentences analyzed by Schlumpf (2015) such as the conditionals, with over 1,100 occurrences, and the adversative clauses, with almost 2,500 occurrences. Another striking difference between these types of sentences concerns their most frequent formal markers: whereas both the conditional and the adversative clauses show a single dominant conjunction used in a high percentage of the cases ( $s i$ is used in over $85 \%$ of the conditional sentences; ma is used in over $65 \%$ of the adversatives), the concessive sentences in the modern Judeo-Spanish texts show two predominant markers, which together are used in almost two-thirds of the cases (see table 1).

\begin{tabular}{|c|c|}
\hline Concessive markers & $\begin{array}{c}\text { Occurrences (percentage) } \\
\text { Total of concessive sentences: } 309\end{array}$ \\
\hline aunque & $92(29,8 \%)$ \\
\hline malgrado (que) & $106(34,3 \%)$ \\
\hline Other concessive conjunctions & $47(15,2 \%)$ \\
\hline Concessives with infinite verb forms & $64(20,7 \%)$ \\
\hline
\end{tabular}

Table 1. Occurrences of concessive markers found in the corpus MemTet

One of the most frequent concessive conjunctions used in the corpus MemTet is aunque 'although', which is also the most common concessive conjunction in Spanish since the $16^{\text {th }}$ century. Aunque is the result of the combination of the temporal adverb aun $<$ Lat. ADHUC 'until there, until then' and the subordinating conjunction que (Bartol Hernández 1986: 199). In Medieval Castilian, que could express different semantic notions, such as causality, finality, consequence, comparison or concessivity. In the case of concessivity, que was 
usually combined with a verb in the subjunctive mood. In order to disambiguate the semantics of que in any specific sentence, scalar particles like mal, encara and aun started to be used in concessive sentences. In Spanish, only aun went through a process of grammaticalization, which led to the creation of the concessive conjunction aunque: the scalar element in aunque no longer refers to a concrete, temporal content ('extension until a certain point of time'), but rather to a more abstract one ('extension to other elements of the same scale', 'inclusion of elements until a certain point') (cf. Batllori / Sánchez / Suñer 2001; Ibba 2008: 735-736; Pérez Saldanya / Salvador 1995; Rivarola 1976: 45-47). It's this origin that explains why aunque still contains a certain notion of scalarity, also visible in some of the Judeo-Spanish examples (e.g., example 4).

In the Judeo-Spanish texts, we have found a total of 92 occurrences $(29,8 \%$ of the concessive clauses) of the concessive conjunction aunque, mostly in narrative, press and dramatic texts. Normally, aunque is combined with a conjugated verb form, mostly in the indicative mood, which also reflects the most common combination in Spanish; however, combinations with other verb forms are possible.

Aunque las piramidas son hoy arancadas y deśregladas, con todo ellas son muy admiradas por los viajadores que vienen cada año de todas las partes del mundo vigitar esta masa colosal. ${ }^{12}$ $\left(\right.$ YERp5,34a-b) ${ }^{13}$

[A/though today the pyramids are demolished and ruined, they are nevertheless deeply admired by the travellers who arrive every year from all parts of the world to visit this colossal mass. $]^{14}$

(2) Mucho más se siente dolor cuando se save que estos honrados źínganos de Rumanía goźan de todas las derechedades de la tiera, mientras que los judíos son considerados como ajenos y condenados a sufrir, aunque ellos cumplan los deveres civiles y militares [...]. (ALVp22,95a)

\footnotetext{
12 We use the transcription system of the journal Sefarad, published by the Instituto de Lenguas y Culturas del Mediterráneo y Oriente Próximo of the Consejo Superior de Investigaciones Científicas (CSIC) in Madrid, including some slight modifications. It's a normalized transcription system, which is based on the Spanish orthography and signals particularities that differentiate the Judeo-Spanish from the Spanish phonology with diacritical marks (cf. Schmid 2006: 78-79). All the graphemes represent the same corresponding sounds as in Spanish with seseo and yeísmo, except for the following: <će,i, ś, ź> = [z], <ge,i, j> = [3], <j, š, čh $>=[]],<j, \hat{g}^{e, i}>=$ $[\mathrm{d} 3],\langle\hat{\mathrm{s}}\rangle=[\mathrm{ts}],\langle\mathrm{h}\rangle=[\mathrm{h}] \circ[\mathrm{X}],\langle\mathrm{b}\rangle=[\mathrm{b}],\langle\mathrm{v}\rangle=[\mathrm{v}] \circ[\beta],\langle|\cdot|\rangle=[\mathrm{II}]$. The author of this article put all the italics and capital letters that appear in the Judeo-Spanish citations, and the exclamation and interrogation marks were put in accordance with the norms of modern Spanish.

13 The whole list of references used to identify the texts included in the corpus MemTet can be found under the following link: https://ladino.unibas.ch/fileadmin/ladino/user_upload/redaktion/Siglas_Corpus.pdf. The minuscule of each reference shows the text genre: $a=$ administrative texts, $c=$ conferences, $d=$ lectures (discursos), $h=$ humoristic texts, $\mathrm{n}=$ narrative texts, $\mathrm{p}=$ press texts, $\mathrm{t}=$ plays $($ teatro $), \mathrm{v}=$ varia .

14 The English translations of the Judeo-Spanish citations are from the author of this article and are based, among others, on the following Judeo-Spanish dictionaries: NehamaDict and BunisLex.
} 
[It's even more painful when it's known that these honorable gypsies from Romania enjoy all the rights of the land, whereas the Jews are considered as foreigners and condemned to suffer, although they fulfill their civil and military duties (...).]

(3) Las conferencias que fueron hechas el año pasado delantre de vośotros, aunque en lingua franceśa, fueron entendidas de la mayor parte de los que vinieron a sentirlas. (ESPc,1)

[The conferences that were held last year in front of you, although in French, were understood by most of the people who came to listen to them.]

Besides the most frequent form, aunque (46 occurrences), we can also find the graphic variant written in two separate words, aun que (29 occurrences) or aun-que (11 occurrences), which points to the formal composite origin of the conjunction. On the other hand, we find some examples of the monophthongized variant anque (6 occurrences), which shows that the form is analyzed as one phonic unit.

(4) La vista de esta mujer, aun que mascada, hiźo estremecer a Armando. (BGn3,21)

[The look of this woman, although masked, made Armando tremble.]

(5)

Víctor.- Si anque tus contos serían justos, la mitad de la dota te quedará intacta. (TSt15,5a)

[Víctor.- Even ifyour stories were right, half of the dowry will stay intact.]

The form anque was also used in Old and Medieval Castilian, and nowadays it is common in popular varieties of Spanish both in Latin America and in Spain (DCECH, s. v. aún). Both variants mentioned above may be interpreted as individual preferences of the involved authors, editors and publishers; nonetheless, it's interesting to observe the phonic coincidence of anque and the Italian conjunction anche. It's possible to postulate a certain phonic influence of the Italian language in more recent times, if we consider that anque is not used in Sephardic texts prior to the modern Italian influence initiated in the mid-19th century.

Despite its high frequency and in contrast with the modern standard Spanish, not aunque but malgrado (que) 'despite, in spite of' is the most common concessive conjunction used in modern Sephardic texts. In the corpus MemTet we have found a total of 106 occurrences of malgrado (que) (34,3\% of the concessive clauses), mostly in narrative and press texts published in Salonika. All of them represent the functions of the Castilian phrases a pesar de (que) and pese a (que), which almost never appear in the Sephardic texts. As in the case of a pesar de (que) and pese a (que) in Spanish, malgrado also is normally combined with noun phrases (e.g., examples 6 and 7 ), whereas the combination of malgrado with the subordinator que and a verb phrase is much less common (e.g., example 8).

(6) -Malgrado tu coraje, tú sos aínda muncho bovo. (NCn,25a)

[-Despite your courage, you are still very naive.] 
[Despite everything they hope to be able to save him.]

Malgrado que esto mos cavśa muchos deśagradamientos y muchas većes diversos gastes que peśgan sovre nuestro buĝeto, nośotros non mos travamos de recivirlos y de testimoñarles nuestra simpatía non solo con biervos, ma también con fatos. (JIDp25,15b)

[Although this causes a lot of displeasure and many times diverse expenses that strain our budget, we do not hesitate to receive them and to demonstrate our affection not only with words, but also with actions.]

In contrast to aunque, malgrado (que) is not part of the Spanish concessive connectives. In contrast, in the two most important contact languages of the modern JudeoSpanish - Italian and French - equivalent forms do exist: malgrado (che) in Italian and malgré (que) in French. Given that malgrado (que) is never used in classical Sephardic texts of the $18^{\text {th }}$ century (cf. García Moreno 2004), we can deduce that the use of malgrado (que) is a characteristic element of the neo-Judeo-Spanish of the second half of the $19^{\text {th }}$ and the $20^{\text {th }}$ centuries. Therefore, we can assume that malgrado (que) was introduced to the Sephardic language during the processes of linguistic innovation and elaboration, motivated by the sociocultural transformations in the Sephardic communities of the Ottoman Empire and, especially, by the influence of the Western European languages.

With regard to the origin of the neologism malgrado (que) in modern Judeo-Spanish, both French and Italian are possible sources. In fact, it's common to adapt French adjectives that end with -é through the Spanish suffix -ado, as we can see, for example, in honorado < Fr. honoré or pasionado < Fr. passionné (cf. Schmid and Bürki 2000: 191). Nevertheless, an Italian origin seems more likely, not especially because of the phonic equivalence of the Italian counterpart, but because most of the occurrences of malgrado (que) can be found in texts that were published in Salonika (63 of the 106 occurrences). Since the beginning of the Sephardic diaspora in the Ottoman Empire, Salonika was an important port where contacts with the Italian merchants and, therefore, with the Italian language were more intense than in other parts of the Empire (cf. Barquín López 1994: 165; Schmid 2008: 62 and 64). That's why the Judeo-Spanish variety of Salonika has always been characterized by its clear influence through the Italian language (cf. Bürki 2012b: 325).

Another concessive marker of Italian origin that was introduced to Judeo-Spanish in the modern period is cuantunque 'although', which shows 10 occurrences in the corpus MemTet. In this case, all the examples are found in texts published in Salonika, mostly in the Sephardic press. Half of them contain a verbal ellipsis in the subordinate clause:

(9) Cuando se parte del miśmo principio, cuantunque por caminos diferentes, siempre se ariva a la miśma fin, al miśmo escopo. (NACp5,2b) 
[When we start from the same principle, although through different ways, we will always reach the same end, the same goal.]

If we look at the few examples in which malgrado (que) is followed by a conjugated verb form (10 occurrences), we notice that all of them use the indicative mood, while in Italian, as well as in French, malgrado (che) and malgré (que) are usually used in combination with the subjunctive mood. ${ }^{15}$ The same observation is valid for cuantunque. This demonstrates a certain preference of Judeo-Spanish for the indicative mood, which is also the case in some other syntactical constructions that take the subjunctive mood in standard Spanish; for example, the hypothetical and counterfactual conditional clauses introduced by the conjunction si (cf. Schlumpf 2015: 196-213), the temporal clauses with cuando that formulate a projection into the future (cf. Berenguer Amador 2012: 55; Bürki and Schmid 2006: 36; García Moreno 2004: 325-327; García Moreno 2006: 47) or the relative clauses introduced by lo que (García Moreno 2004: 324-325).

Considering the diachronic dimension of the use of aunque and malgrado (que), the most important point is the fact that the latter is only found in modern Sephardic texts, whereas the former is also used in Judeo-Spanish texts of earlier epochs. If we only focus on the decades represented in the corpus MemTet (1880-1930), we can observe the following (see table 2): in the texts published between 1880 and 1900, more than half of the concessive clauses introduced by one of the two main conjunctions use aunque $(52,2 \%)$; in contrast, in the texts published between 1901 and 1930, it's more common to find concessive sentences using malgrado (que) (56,5\%). The increase of the percentage corresponding to malgrado (que) between the $19^{\text {th }}$ and the $20^{\text {th }}$ century is almost $10 \%$, an additional proof of its character as a neologism: it was introduced to the Judeo-Spanish language in the late $19^{\text {th }}$ century and reaches a considerable diffusion until 1900, but its consolidation goes even further in the $20^{\text {th }}$ century, when its frequency becomes higher than that of the patrimonial Castilian form aunque.

\begin{tabular}{|l|c|c|}
\hline & $\begin{array}{c}\text { Occurrences of aunque } \\
\text { Total: } 92 \text { occurrences }\end{array}$ & $\begin{array}{c}\text { Occurrences of malgrado (que) } \\
\text { Total: } 106 \text { occurrences }\end{array}$ \\
\hline $\begin{array}{l}\mathbf{1 8 8 0}-1900 \\
\begin{array}{l}\text { Total: } 67 \text { occurrences of } \\
\text { aunque and malgrado (que) }\end{array}\end{array}$ & 35 out of $67=\mathbf{5 2 , 2} \%$ & 32 out of $67=47,8 \%$ \\
\hline $\begin{array}{l}\mathbf{1 9 0 1 - 1 9 3 0} \\
\begin{array}{l}\text { Total: } 131 \text { occurrences of } \\
\text { aunque and malgrado (que) }\end{array}\end{array}$ & 57 out of $131=43,5 \%$ & 74 out of $131=\mathbf{5 6 , 5 \%}$ \\
\hline
\end{tabular}

15 See Grevisse and Goosse (1980: 1563-1564 and 1571) and Klare (1958: 62-66 and 138) for French; GarzantiDiz (s. v. malgrado) and ZingarelliVoc (s. v. malgrado) for Italian. 
Table 2. Frequency of concessive clauses with aunque or malgrado (que) in Sephardic texts published until 1900 and after 1900

Another indicator for the interpretation of malgrado (que) as a neologism of Western European origin can be found when we look at the use of the two conjunctions in the different text genres, especially when we compare its frequency in the press versus in the plays (see table 3).

\begin{tabular}{|l|c|c|}
\hline & $\begin{array}{c}\text { Occurrences of concessive } \\
\text { clauses with aunque } \\
\text { (percentage) } \\
\text { Total: 92 occurrences }\end{array}$ & $\begin{array}{c}\text { Occurrences of concessive } \\
\text { clauses with malgrado } \\
\text { (que) (percentage) } \\
\text { Total: 106 occurrences }\end{array}$ \\
\hline Administrative texts & - & $2(1,9 \%)$ \\
\hline Conferences & $4(4,4 \%)$ & $9(8,5 \%)$ \\
\hline Lectures & $5(5,4 \%)$ & $3(2,8 \%)$ \\
\hline Press texts & $\mathbf{2 1 ( 2 2 , 8 \% )}$ & $\mathbf{4 2 ( 3 9 , 6 \% )}$ \\
\hline Narrative texts & $44(47,8 \%)$ & $43(40,6 \%)$ \\
\hline Plays & $\mathbf{1 5 ( 1 6 , 3 \% )}$ & $\mathbf{5 ( 4 , 7 \% )}$ \\
\hline Humoristic texts & - & $2(1,9 \%)$ \\
\hline Varia & $3(3,3 \%)$ & \\
\hline
\end{tabular}

Table 3. Frequency of concessive clauses with aunque or malgrado (que) in different text genres ${ }^{16}$

In the case of journalistic texts, the percentage of malgrado (que) is considerably higher than the one of aunque: $39,6 \%$ of the occurrences (42 out of 106) of malgrado (que) are located in press texts, whereas only $22,8 \%$ of the occurrences (21 out of 92) of aunque are found in this text genre. The press is a genre that typically helps to introduce and spread linguistic innovations throughout a linguistic community and that, therefore, is generally one of the first text genres to reflect such linguistic innovations. On the contrary, the percentages observed in plays are different: only $4,7 \%$ of the occurrences (5 out of 106) of malgrado (que) are opposed to $16,3 \%$ of the occurrences (15 out of 92) of aunque. The language used in the Sephardic theatre is more traditional than the one used in the press; additionally, the theatrical language reflects a more oral and informal register than the written press. It seems, therefore, that at least until 1930 malgrado (que) is predominantly a solution of the written, more formal and more elaborate Judeo-Spanish, while aunque is used with more regularity in all the different registers and text genres. We can also deduce, finally, that the neologism

16 The percentages of the different text genres in MemTet are as follows: administrative texts (4\%), conferences $(5 \%)$, lectures $(6 \%)$, narrative texts $(34 \%)$, press texts $(29 \%)$, plays $(18 \%)$, humoristic texts $(2 \%)$, varia $(2 \%)$. 
malgrado (que) entered the Sephardic language through the written and not through the oral language.

In sum, the patrimonial concessive conjunction aunque, which Judeo-Spanish inherited from Medieval Castilian, is found in Sephardic texts of different centuries and text genres, whereas the modern Romance neologism malgrado (que) only started to be used in the late $19^{\text {th }}$ century and turned into the most common concessive marker in written Judeo-Spanish texts during the first decades of the $20^{\text {th }}$ century. We assume that it was first introduced in written Judeo-Spanish and that it is more typical for formal text genres than for more informal or even colloquial ones. We also remember that aunque is commonly used in combination with verb phrases, while malgrado (que) normally introduces noun phrases. Therefore, we can conclude that the election of one of the two main concessive conjunctions depends on a series of syntactical, geographical, diachronic, textual and contextual factors and that the introduction and diffusion of malgrado (que) reflect the general transformations of the JudeoSpanish language in the late $19^{\text {th }}$ and early $20^{\text {th }}$ centuries.

\subsection{Results of language contacts in the scalar concessive conditionals of modern Judeo- Spanish: Hebrew and French influence}

The last part of this study is dedicated to the scalar concessive conditionals in JudeoSpanish, where the influences of two completely different contact languages can be observed. As explained before, the scalar concessive conditionals in modern Spanish are usually introduced by incluso si 'even if' or, in negative sentences, by ni siquiera si 'not even if'. Furthermore, aunque frequently expresses scalar concessivity, typically combined with subjunctive imperfect or, in substandard varieties, with a conditional verb form. The first observation about the scalar concessive conditionals in the Sephardic texts is surprising: neither of the most canonical Spanish phrases, incluso si and ni siquiera si, appears in the corpus MemTet. On the contrary, the majority of the scalar concessive conditionals in the corpus use loan elements from foreign languages.

On the one hand, the Hebrew loanword afilú 'even if, even though' (BunisLex 263) can be found in the Sephardic texts, not only in the corpus MemTet but also in Sephardic texts of the classical period (18 $18^{\text {th }}$ century). Afilú did already exist in Rabbinic Hebrew and was, originally, a complex conjunction formed by [Hebrew] / af 'also' and [Hebrew] / ilú, a subordinating conjunction used in counterfactual conditional clauses in Rabbinic and still in contemporary Hebrew. Furthermore, ilú is a complex form composed of the conditional conjunction $\mathrm{im}$, used generally in factual conditional clauses, and $l u$, used to form counterfactual conditional clauses in Biblical Hebrew (cf. Gesenius 1909: 316, §104.2 and 518, §158.3; Meyer 1989: 303, §88.1 and 402, §122.4). In the Sephardic texts, afilú usually appears in combination with a conjunction (cuando or que) and a conjugated verb. 
Afilú cuando se trata de haćinura sémpliche, la madre, que tiene menester de repośo, es ovligada de despertarse cada punto porque el chico está despierto o llora o quiere la teta [...]. (EPp83,211a)

[Even if it's an easy illness, the mother, who needs some rest, is obliged to wake up all the time because the child is awake or cries or wants to be nursed (...).]

(11) Porque el jidió..., afilú que beve mucho vino, no se embo-boracha nunca... Nunca él no está bobo-bo... (MAZt,56a)

[Because the Jew..., even if he drinks a lot of wine, does not get dru-unk ever... He is never druu-u...]

In Hebrew, the particle [Hebrew] / afilú "can have purely conditional value", whereas "in its concessive function it signals an exceptional circumstance". Indeed, "it is unusualness of a condition or circumstance that predominates rather than its [purely] concessive aspect" (Pérez Fernández 1999: 241); this is exactly what we can observe in the Judeo-Spanish examples. Further, it is interesting to note that the same Hebrew loanword is also used in Yiddish, the language of the Ashkenazi Jews, in the form of afile or afile ven (cf. Birnbaum 2011: 109; Haspelmath and König 1998: 596):

Afile veris regnt oder di zun scheynt, veln mir geyn in droysn.
even if it rains or the sun shines will we go in outside

'Whether it rains or the sun shines, we will go outside.'

(Example adapted from Haspelmath and König 1998: 596)

As in Judeo-Spanish, the Yiddish form afile has maintained its original significance that is found in rabbinical Hebrew; that is, 'even though, even if'. Therefore, today this particle [Hebrew] / afilú / afile is a linguistic marker of scalar concessive conditionality used in most parts of the Jewish-speaking world.

However, if we consider again the results obtained in the corpus MemTet, we see that afilú is not the most frequent marker of scalar concessive conditionals in modern Sephardic texts, but miśmo sil si miśmo, ${ }^{17}$ a calque from the French construction même si / si même. In more than two-thirds of the occurrences, miśmo si / si miśmo introduces a verbal phrase with a conjugated verb form in the indicative mood, but some occurrences of the subjunctive mood and conditional verb forms also can be found. Usually, the adverb miśmo is located in the first place followed by the conjunction si (miśmo s/), but the opposite case is also possible (si miśmo), comparable to French.

\footnotetext{
${ }_{17}$ Normally, in the original aljamia texts, miśmo is written with the Hebraic letter źayin, but it can also be found with sámej.
} 
Yo vo ir con vos, miśmo sime vaš a llevar al inferno. (BGn7,21)

[I will go with you, even if you take me to hell.]

(13) Vośotros havlateš dunque mentira, él va tornar y yo lo vo esperar, mismo si duviere pasar la nochada entera a la puerta de la calle. (GUEt9,18a)

[Thus you were lying, he will come back and I will wait for him, even if I have to stay the whole night at the door in the street.]

(14) Sačhel - Si mismo toda tu familla estaría haćina, yo no te daría más de un florín. (GUEt5,17b18a)

[Sačhel - Even if your entire family were ill, I wouldn't give you more than one florín ('coin').]

Some other, rather exceptional scalar concessive conditional constructions can be found in the Sephardic texts. Normally, they also use the adverbial element miśmo (for example, miśmo que < Fr. même que) and / or subjunctive verb forms.

(15) Del resto, al otro día es Noel y no tenemos escola. Miśmo que me levanto un poco tadre, no importa... (HANt,4a)

[Otherwise, the next day is Christmas and there is no school. Even if / get up a bit late, it doesn't matter...]

(16) Miśmo que me aroguen mucho y que se metan de ĝinollos delantre de mí, yo no vo a dar más moneda... (MAZt,49b)

[Even if they beg me a lot and go down on bended knees in front of me, I will not give more money...]

(17) Cualunque elevo que se absenta, fuese miśmo un medio día, devrá trayer una justificación; en el cavśo contrario, él devrá ser apenado, y si la absencia se repeta frecuentemente, el elevo en cuestión será mandado proviśoriamente o definitivamente de la escola. $(\mathrm{ECa}, 14)$

[Whatever pupil stays away, even if it's only half a day, has to bring a justification; otherwise, he will be punished, and if the absence is repeated frequently, the pupil in question will be thrown out of school temporarily or definitively.]

(18) Y como ya lo devéš saver, los ladrones, sean ellos los más hábiles, heśitan a haćer sus colpo cuando topan en sus camino enemigos semejantes... (LXn,43)

[And as you already know, the thieves, even if they are the most skilled ones, hesitate to carry out their coups when similar enemies get in their way...]

Without any doubt, the Hebrew loanword afilú represents the importance of the linguistic and cultural influence of Hebrew during the first centuries of the Sephardic diaspora and constitutes, therefore, a typical element of the classical Judeo-Spanish, maintained in the modern period. Very different are the situation, origin and character of miśmo si / si miśmo, which is inexistent in classical Judeo-Spanish texts: it reflects the processes of 
elaboration and innovation that affected the Judeo-Spanish language since the middle of the $19^{\text {th }}$ century and above all followed the example of the French language, which was at that time a symbol of progress and modernity. These conclusions can be supported by the quantitative analysis of the occurrences of afilú and miśmo si / si miśmo in the Sephardic corpus: 15 occurrences of afilú are in opposition to 30 occurrences of miśmo si / si miśmo. Hence, transformations in the Judeo-Spanish language in the $19^{\text {th }}$ century did not just lead to the introduction of a new marker of scalar concessive conditionality; this new marker, based on a French model, is even more frequently used than the classical loanword of Hebrew origin, afilú. This replacement and the rapid diffusion of the French calque constitute only one of many examples of the leading role of the French language in the linguistic modernization of the classical Judeo-Spanish and its transformation into the neo-Judeo-Spanish. In addition, the lesser use of afilú demonstrates the tendency of the modern Judeo-Spanish to replace traditional elements of Hebrew and Turkish origin with elements adopted from French and Italian. In this way, the language becomes a crucial medium and a useful indicator of this overall modernization process of the Sephardic communities in the Ottoman Empire.

\section{Conclusions}

The case of the concessive and concessive conditional sentences in modern Judeo-Spanish shows the importance of taking into account the grammatical elements of a language in the studies of language contacts. Although results of language contacts generally are more numerous on the phonetic and purely lexical levels, they also appear in elements such as the conjunctions, which are crucial linguistic elements for the construction of complex sentences.

Considering the concessive examples found in the corpus MemTet, we have observed different results of language contacts of Judeo-Spanish in the modern period. On the one hand, we have observed that in the last decades of the $19^{\text {th }}$ century a new concessive conjunction entered into the Judeo-Spanish paradigm: malgrado (que). This form is of Western European origin, most likely a loanword from Italian, used more frequently in texts that were published in Salonika. This example shows the importance of certain contextual factors such as the place of origin of the texts, which allows us to postulate an Italian rather than a French origin for this loanword. Concerning its functions, malgrado (que) not only complements the inventory of concessive conjunctions in Judeo-Spanish, but also diversifies it: whereas the canonical, traditional concessive conjunction aunque is generally used in combination with verb phrases, the neologism malgrado (que) normally introduces noun phrases and reflects, therefore, the typical standard Spanish constructions with a pesar de (que) or pese a (que), which can hardly ever be found in Sephardic texts. Another result of 
the contact of Judeo-Spanish and Italian in the modern period is the concessive conjunction cuantunque, though this is much less frequent than malgrado (que).

On the other hand, the analysis of the scalar concessive conditionals in the corpus MemTet has shown not only the results of various and very different language contacts, but also a partial replacement of the loaned elements between the classical and the modern period. The Hebraism afilú is a representative loanword from the formation period of JudeoSpanish: it is already used in classical Sephardic texts of the $18^{\text {th }}$ century and shows the predominance of the Hebrew culture and language as a point of reference during the first centuries of the Sephardic diaspora in the Ottoman Empire. In contrast, miśmo si / si miśmo is a modern calque based on the French même si / si même, introduced to Judeo-Spanish during the last decades of the $19^{\text {th }}$ century. Miśmo si / si miśmo is a perfect example of the modernization period of the Sephardic language since the opening of the communities to the European cultures and languages. French is introduced in the Ottoman Sephardic world as a language that brings along modernity, emancipation and progress; it is taught in the AIU schools, which are crucial elements in the modernization process of the communities; and as a consequence, it turns out to be the most important contact language of Judeo-Spanish toward the end of the $19^{\text {th }}$ century and still during the first decades of the $20^{\text {th }}$ century. Many Gallicisms characterize the elaboration processes that led to the creation of neo-JudeoSpanish, and although many of them denote objects and concepts related to the modern world, others substitute terms that are considered more traditional, such as Turkish or Hebrew words. That is the case of miśmo si / si miśmo: although an equivalent form exists in Judeo-Spanish with the Hebraism afilú, the Sephardic authors represented in MemTet prefer the more modern form based on the French language.

The transformations observed in the concessive markers of modern Judeo-Spanish are closely linked to the overall modernization that characterizes the history of the Sephardic language at the end of the $19^{\text {th }}$ and the beginning of the $20^{\text {th }}$ centuries. In particular, the introduction of new text genres and the extensive production of written texts accelerated the process of language elaboration and provided an important impulse for innovations not only in the lexicon, but also in grammatical elements such as conjunctions. This case study about the concessive clauses in modern Judeo-Spanish should be complemented by studies about other types of complex sentences such as the causal, final, comparative or consecutive sentences (for the conditional and adversative sentences, see Schlumpf 2015) in order to show the broad variety of impacts that the different language contacts had throughout the history of Judeo-Spanish. 


\section{Cited bibliography}

Barnaï, Jacob. 1992. Los sefardíes en el Imperio Otomano (siglos XV-XIX). In María Antonia Bel Bravo (coord.), Diáspora sefardí, 93-151. Madrid: Mapfre.

Barquín López, Amelia. 1994. La lengua de las novelas de Alexander Ben-Guiat. In Tamar Alexander, Abraham Haim, Galit Hasan-Rokem \& Ephraim Hazan (eds.), History and Creativity in The Sephardi and Oriental Jewish Communities. The Third International Congress for Research on the Sephardi and Oriental Jewish Heritage, 161-189. Jerusalem: Misgav Yerushalayim.

Bartol Hernández, José Antonio. 1986. Oraciones consecutivas y concesivas en las Siete Partidas (Studia Philologica Salmanticensia, Anejos, Textos y ensayos 16). Salamanca: Universidad de Salamanca.

Batllori, Montse, Carlos Sánchez \& Avelina Suñero. 2001. La evolución del sistema de nexos adverbiales del español: un proceso cíclico entre pragmática y sintaxis (el caso de que). In José Jesús de Bustos Tovar, Patrick Charaudeau, José Luis Girón Alconchel, Silvia Iglesias Recuero \& Covadonga López Alonso (eds.), Lengua, discurso, texto (I Simposio Internacional de Análisis del Discurso), 2 vols, vol. I, 227-239. Madrid: Visor Libros.

Benbassa, Esther \& Aron Rodrigue. 2004. Historia de los judíos sefardíes. De Toledo a Salónica. Madrid: Abada Editores.

Berenguer Amador, Ángel. 2012. La sintaxis del subjuntivo en judeoespañol. eHumanista 20. 4762.

Birnbaum, Salomo. 2011 [1917]. Praktische Grammatik der Jiddischen Sprache (LINCOM Gramatica 87). München: LINCOM.

Britannica = Encyclopaedia Britannica Online Academic Edition. 2013. Chicago: Encyclopædia Britannica, Inc. http://www.britannica.com (accessed 15 November 2016).

BunisLex $=$ Bunis, David M. 1993. A lexicon of the Hebrew and Aramaic elements in modern Judezmo. Jerusalem: Magnes Press \& Hebrew University.

Bürki, Yvette. 2012a. Mecanismos de cohesión gramatical en textos periodísticos en neojudeoespañol. In Yvette Bürki \& Carsten Sinner (eds.), Tiempo y espacio y relaciones espacio-temporales en judeoespañol, 125-140. München: Peniope.

Bürki, Yvette. 2012b. El discurso periodístico en judeoespañol. El Avenir y La Época de Salónica (1901-1902). Basel: Universität Basel dissertation.

Bürki, Yvette \& Beatrice Schmid. 2006. El tiempo futuro en judeoespañol: apuntes para su estudio. In Hilary Pomeroy (ed.), Proceedings of the Thirteenth British Conference on Judeo-Spanish Studies (7-9 September, 2003), 27-41. London: Department of Hispanic Studies, Queen Mary, University of London.

Cimeli, Manuela. 2013. Encuentros literarios entre Asquenaz y Sefarad: la recepción en la literatura judeoespañola de la obra narrativa de los hermanos Philippson y de Marcus Lehman. Basel: Universität Basel dissertation. 
http://edoc.unibas.ch/29241/1/DRUCKVERSION_DISS_Elektronisch-2.pdf (accessed 15 November 2016).

DCECH = Corominas, Joan. 1980-1991. Diccionario crítico etimológico castellano e hispánico, 6 vols. Madrid: Gredos.

De Benmergui, Alicia V. 2007. Historia de la familia Camondo. Milim Cultural. http://milimcultural.com.ar/historia-de-la-familia-camondo (accessed 15 November 2016).

Di Meola, Claudio. 1998. Zur Definition einer logisch-semantischen Kategorie: Konzessivität als 'versteckte Kausalität'. Linguistische Berichte 175. 329-352.

Díaz-Mas, Paloma. 2006 [1986]. Los Sefardíes: historia, lengua y cultura, 4th edn. Barcelona: Riopiedras.

Faroqhi, Suraiya. 2003 [1995]. Kultur und Alltag im Osmanischen Reich. Vom Mittelalter bis zum Anfang des 20. Jahrhunderts, 2nd edn. München: C. H. Beck.

Flamenco García, Luis. 1999. Las construcciones concesivas y adversativas. In Ignacio Bosque \& Violeta Demonte (dirs.), Gramática descriptiva de la lengua española. Vol. III: Entre la oración y el discurso. Morfología, 3805-3878. Madrid: Espasa Calpe.

Gaon, Moshe David. 1965. [Hebrew] [A bibliography of the Judeo-Spanish (Ladino) press]. Jerusalem: Ben-Zvi Institute \& The Hebrew University.

García Moreno, Aitor. 2004. Relatos del pueblo ladinán (Me'am Lo'eź de Éxodo) (Publicaciones de Estudios Sefardíes 9). Madrid: CSIC.

García Moreno, Aitor. 2006. Innovación y arcaísmo en la morfosintaxis del judeoespañol clásico. In Yvette Bürki, Beatrice Schmid \& Armin Schwegler (eds.), Una lengua en la diáspora: el judeoespañol de Oriente (Revista Internacional de Lingüística Iberoamericana IV, 2 [8], Sección temática), 35-51. Madrid: Iberoamericana Editorial Vervuert.

GarzantiDiz = Patota, Giuseppe (dir.). 2008. Garzanti Italiano. I grandi dizionari. Milano: Garzanti Linguistica.

Gesenius, Wilhelm. 1909 [1813]. Hebräische Grammatik, 28th edn., revised and edited by E. Kautzsch. Leipzig: Vogel.

Grevisse, Maurice \& Goosse, André. 2011 [1936]. Le bon usage. Grammaire française, 15th edn. Bruxelles: Groupe De Boeck.

Harris, Tracy K. 1982. Reasons for the decline of Judeo-Spanish. In Tracy K. Harris (ed.), Sociology of Judezmo. The language of the Eastern Sephardim (International Journal of the Sociology of Language 37), 71-97. Amsterdam: Mouton.

Harris, Tracy K. 1985. The decline of Judezmo: problems and prospects. In Joshua A. Fishman (ed.), Readings in the Sociology of Jewish Languages, 195-210. Leiden: Brill.

Harris, Tracy K. 1994. Death of a language. The history of Judeo-Spanish. Newark, London \& Toronto: University of Delaware Press \& Associated University Presses.

Haspelmath, Martin \& Ekkehard König. 1998. Concessive conditionals in the languages of Europe. In Johan Van der Auwera \& Dónall P. Ó Baoill (eds.), Adverbial constructions in the languages of Europe, 563-640. Berlin \& New York: Mouton de Gruyter. 
Hassán, lacob M. 1966. El estudio del periodismo sefardí. Sefarad 26(1). 229-235.

Hassán, lacob M. 1995. El español sefardí (judeoespañol, ladino). In Manuel Seco \& Gregorio Salvador (coords.), La lengua española, hoy, 117-140. Madrid: Fundación Juan March.

Ibba, Daniela. 2008. Metáfora, metonimia y matizadores concesivos: hacia la gramaticalización de los conectores concesivos. In Concepción Company Company \& José G. Moreno de Alba (eds.), Actas del VII Congreso Internacional de Historia de la Lengua Española. Mérida (Yucatán), 4-8 de septiembre de 2006, 2 vols., vol. I, 731-744. Madrid: Arco Libros.

$\mathrm{JE}=$ Jewish Encyclopedia. The unedited full-text of the 1906 Jewish Encylopedia. 2002-2011. The Kopelman Foundation. http://www.jewishencyclopedia.com (accessed 15 November 2016).

Klare, Johannes. 1958. Entstehung und Entwicklung der konzessiven Konjunktionen im Französischen. Berlin: Akademie-Verlag.

König, Ekkehard. 1981. The meaning of scalar particles in German. In Hans-Jürgen Eikmeyer \& Hannes Rieser (eds.), Words, worlds, and contexts. New approaches in word semantics, 107-132. Berlin \& New York: Walter de Gruyter.

König, Ekkehard. 1985. Where do concessives come from? On the development of concessive connectives. In Jacek Fisiak (ed.), Historical semantics. Historical word-formation, 263282. Berlin, New York \& Amsterdam: Mouton Publishers.

König, Ekkehard. 1988. Concessive connectives and concessive sentences: cross-linguistic regularities and pragmatic principles. In John A. Hawkins (ed.), Explaining language universals, 145-166. Oxford \& Cambridge: Basil Blackwell.

König, Ekkehard. 1991. Konzessive Konjunktionen. In Armin Von Stechow \& Dieter Wunderlich (eds.), Semantik. Semantics. Ein internationales Handbuch der zeitgenössischen Forschung. An international handbook of contemporary research (Handbücher zur Sprachund Kommunikationswissenschaft. Handbooks of linguistics and communication science. Manuels de linguistique et des sciences de communication 6), 631-639. Berlin \& New York: Walter de Gruyter.

König, Ekkehard \& Peter Eisenberg. 1984. Zur Pragmatik von Konzessivsätzen. In Gerhard Stickel (ed.), Pragmatik in der Grammatik, 313-332. Düsseldorf: Pädagogischer Verlag Schwann-Bagel.

Levy, Avigdor. 1992. The Sephardim in the Ottoman Empire. Princeton \& New Jersey: The Darwin Press.

Lévy, Francine. 1990. L'oeuvre de I'Alliance Israélite Universelle (I'AIU). Études de linguistique appliquée 78. 97-107.

Molho, Rena. 1993. Education in the Jewish community of Thessaloniki in the beginning of the twentieth century. Balkan Studies 34.2. 259-269.

Meyer, Rudolf. 1989. Gramática de la lengua hebrea. Translated from German by Ángel SáenzBadillos. Barcelona: Riopiedras. 
NehamaDict $=$ Nehama, Joseph. 1977. Dictionnaire du judéo-espagnol. In collaboration with Jesús Cantera. Madrid: CSIC.

Pérez Fernández, Miguel. 1999. An introductory grammar of rabbinic hebrew. Translated from Spanish by John Elwolde. Leiden, Boston \& Köln: Brill.

Pérez Saldanya, Manuel \& Vicent Salvador. 1995. Fraseologia de l'encara i processos de gramaticalització. Caplletra 18. 85-108.

Rieder-Zelenko, Elena. 2014. El léxico relacionado con la vida urbana en La Buena Esperanza. In Yvette Bürki \& Elena Romero (eds.), La lengua sefardí. Aspectos lingüísticos, literarios y culturales, 135-150. Berlin: Frank \& Timme.

Rivarola, José Luis. 1976. Las conjunciones concesivas en español medieval y clásico. Contribución a la sintaxis histórica española. Tübingen: Niemeyer.

Rodrigue, Aron. 1990. French Jews, Turkish Jews. The Alliance Israélite Universelle and the politics of Jewish schooling in Turkey, 1860-1925. Bloomington \& Indianapolis: Indiana University Press.

Rodrigue, Aron. 1993. Images of Sephardi and Eastern Jewries in transition. The teachers of the Alliance Israélite Universelle, 1860-1939. Seattle \& London: University of Washington Press.

Rodríguez Rosique, Susana. 2008. Pragmática y Gramática. Condicionales concesivas en español (Studien zur romanischen Sprachwissenschaft und interkulturellen Kommunikation 47). Frankfurt am Main: Peter Lang.

Romero, Elena. 1979. El teatro de los sefardíes orientales, 3 vols. Madrid: CSIC.

Romero, Elena. 1992. La creación literaria en lengua sefardí. Madrid: Mapfre.

Romero, Elena. 2007. La literatura sefardí: de la tradición a los tiempos modernos. In Pedro M. Piñero Ramírez (coord.), La memoria de Sefarad. Historia y cultura de los sefardíes, 173205. Sevilla: Fundación Sevilla NODO \& Fundación Machado.

Romero, Elena. 2008a. Historia y literatura. In lacob M. Hassán, Ricardo Izquierdo Benito (coords.) \& Elena Romero (ed.), Sefardies: Literatura y lengua de una nación dispersa (Colección Humanidades 96), 155-192. Cuenca: Universidad de Castilla-La Mancha.

Romero, Elena. 2008b. La literatura dramática. In lacob M. Hassán, Ricardo Izquierdo Benito (coords.) \& Elena Romero (ed.), Sefardíes: Literatura y lengua de una nación dispersa (Colección Humanidades 96), 421-486. Cuenca: Universidad de Castilla-La Mancha.

Sánchez, Rosa. 2010. Un personaje prototípico del teatro sefardí oriental: acerca de la galiparla del franquito. In Paloma Díaz-Mas \& María Sánchez Pérez (eds.), Los sefardíes ante los retos del mundo contemporáneo. Identidad y mentalidades, 87-97. Madrid: CSIC.

Schlumpf, Sandra. 2015. Condicionalidad y concesividad en judeoespañol moderno. Teoría y análisis de corpus (Hispanica Helvetica 27). Sociedad Suiza de Estudios Hispánicos \& Pórtico Librerías, Lausanne \& Zaragoza.

Schmid, Beatrice. 2006. La transcripción de datos judeoespañoles de fuentes aljamiadas. In Yvette Bürki \& Elwys De Stefani (eds.), Trascrivere la lingua. Dalla filologia all'analisi 
conversazionale. Transcribir la lengua. De la Filología al Análisis Conversacional, 63-83. Bern: Peter Lang.

Schmid, Beatrice. 2008. La lengua sefardí en su plenitud. In lacob M. Hassán, Ricardo Izquierdo Benito (coords.) \& Elena Romero (ed.), Sefardíes: Literatura y lengua de una nación dispersa (Colección Humanidades 96), 51-79. Cuenca: Universidad de Castilla-La Mancha.

Schmid, Beatrice \& Yvette Bürki. 2000. "El haćino imaginado": comedia de Molière en versión judeoespañola. Edición del texto aljamiado, estudio y glosario (ARBA 11). Basel: Romanisches Seminar der Universität Basel.

Shaw, Stanford Jay. 1991. The Jews of the Ottoman Empire and the Turkish Republic. Basingstoke \& London: Macmillan.

Veinstein, Gilles. 1993. El Imperio Otomano, desde 1492 hasta finales del siglo XIX. In Henry Méchoulan (dir.), Los judíos de España. Historia de una diáspora, 1492-1992, 347-372. Madrid: Trotta.

Weiker, Walter F. 1992. Ottomans, Turks and the Jewish polity. A history of the Jews of Turkey. Lanham, New York \& London: University Press of America \& The Jerusalem Center for Public Affairs.

ZingarelliVoc = Zingarelli, Nicola. 2016 [1917-1921]. Lo Zingarelli. Vocabolario della lingua italiana, 12nd edn., reprint. Bologna: Zanichelli. 